\title{
Geophysical characterization of bottom simulating reflectors in the Fairway Basin (off New Caledonia, Southwest Pacific), based on high resolution seismic profiles and heat flow data
}

\author{
Hervé Nouzéa ${ }^{\text {, Emmanuel Cosquer }}{ }^{\mathrm{a}}$, Julien Collot ${ }^{\mathrm{a}, \mathrm{b}}$, Jean-Paul Foucher ${ }^{\mathrm{a}}$, Frauke \\ Klingelhoefer ${ }^{a}$, Yves Lafoy ${ }^{b}$ and Louis Gélia, *
}

\author{
a Ifremer, Marine Geosciences Department, BP 70, 29280, Plouzané, France \\ ${ }^{b}$ Geological Survey of New Caledonia, Department of Industry, Mines and Energy of New Caledonia, BP 465, \\ 98845 Nouméa cedex, New Caledonia \\ *: Corresponding author : L. Géli, email address : geli@ifremer.fr
}

\begin{abstract}
:
High-resolution reflection and refraction seismic data were collected in 2004 to investigate, in further detail than allowed by pre-existing low resolution seismic data, the nature of a Bottom Simulating Reflector (BSR) that extends over a broad area of the Fairway Basin, a rifted, continental structure located on the eastern flank of the Lord Howe Rise, to the southwest of New Caledonia. Two main reflectors are documented: the shallower $(R N)$ mimics the seafloor and has a negative polarity while the deeper (RP) does not always mimic the seafloor and has a positive polarity. Using the existing regional seismic lines, we can show that reflector RN can be continuously followed up to DSDP 208 drill hole site. Reflector RP is discontinuous and cannot be traced to DSDP 208. Based on DSDP 208 stratigraphic data, Reflector RN is assigned to the Eocene/Oligocene regional unconformity; reflector $\mathrm{RP}$ is interpreted in terms of a diagenetic BSR, likely related to an Opal-A/Opal-CT transition front. Heat flow data collected in 2006 suggest that reflector RP lies too deep to be related to methane hydrates, strengthening our interpretation that RP is of diagenetic origin.
\end{abstract}

Keywords: BSR; Fairway Basin; Southwest Pacific; geophysics; gas hydrates; stratigraphy

\section{Introduction}

Following R/V "Rig Seismic" AGSO Surveys 177 (e.g. Ramsay et al., 1997) and 206 (e.g. [Lafoy et al., 1998] and [Bernardel, 1999]), a Bottom Simulating Reflector (BSR) was identified (Fig. 1 and Fig. 2) in the southernmost part of the Central Fairway Basin (Exon et al., 1998). This BSR was later shown, from ZoNeCo 5 cruise data (Auzende et al., 2000a J.-M. Auzende, S. Van de Beuque, G. Dickens, C. François, Y. Lafoy, O. Voutay and N. Exon, Deep sea diapirs and bottom simulating reflector in Fairway basin (SW Pacific), Marine Geophysical Researches 21 (2000), pp. 579-587. Full Text via CrossRef | View Record in Scopus | Cited By in Scopus (10)Auzende et al., 2000a), to extend further north in the Central Fairway Basin, over an area of several tens of thousands of km2 located in the offshore domain of New Caledonia (Auzende et al., 2000a). The BSR lies at a depth of 500-600 m. It was described as clearly 
cross-cutting sedimentary strata, but of small amplitude and with a positive polarity.

For a general review, refer to Exon et al. (2007). Based on previous work by Exon et al. (2004a), Pecher (2004) and Nouzé et al. (2005), it is proposed that the BSR in the Fairway could result from: 1) a diagenetic phase transformation; 2) a thin gas layer with a sharp top; or 3) the sharp base of a gas layer (probably beaneath gas hydrates) of thermogenic origin. As part of the ZoNeCo-11 cruise of R/V L'Atalante in 2004, further seimic field work was carried out in the Fairway basin (Figure 1) to investigate the BSR distribution and its properties in considerably greater detail than allowed by previously collected low resolution seismic data (ZoNeCo 5). Four 2D high resolution reflection seismic lines (Z11-11 to Z11-14) were shot and recorded on 12 Ocean Bottom Seismometers (OBS). The seismic study was further complemented by heat flow measurements taken at five distinct sites of the Fairway Basin with R/V Marion Dufresne during the ZoNeCo-12/Ausfair cruise (Foucher and scientific party, 2006). Here, we present these newly acquired seismic and heat flow data and discuss the nature of the BSR in the Fairway Basin.

\section{Regional geological context}

The Fairway Basin is located between Australia and New Caledonia. It extends over about $800 \mathrm{~km}$ in a NNW-SSE direction. It is 120-200 km wide, limited to the SW by the Lord Howe Rise and separated from the New Caledonia basin by the Fairway Ridge to the NE (Figure 1). In the Fairway Basin, seafloor depth increases southwards, from $\sim 1500 \mathrm{~m}$ to $\sim 3000 \mathrm{~m}$, as well as the sedimentary thickness - from about $2000 \mathrm{~m}$ in the North Fairway Basin, up to 4000m in the South Fairway Basin (e.g. Auzende et al., 2000a; 2000b).

The Fairway Basin was interpreted until recently (e.g. Ravenne et al., 1977; Lafoy et al., 1994), as an oceanic basin resulting from the fragmentation of the eastern Gondwana during the Late Cretaceous and Early Palaeogene (82-52 Ma) (e.g. Weissel and Hayes, 1972; Hayes Dennis and Ringis, 1973; Gaina et al., 1998). Based on new refraction and reflection seismic data, it is now proposed that it has developed on a thinned continental crust (Lafoy et al., 2005; Klingelhoefer et al., 2007).

Using previous seismic surveys (Van de Beuque et al., 1998, 2003; Auzende et al., 2000c; Exon et al., 2004b) and DSDP drilling (e.g. Burns et al., 1973d; 1973b), Exon et al. (2007) have proposed a regional stratigraphy comprising three main sedimentary units. Upper Cretaceous and pre-Upper Cretaceous sequences (Unit 3) appear on seismic sections as a poorly bedded unit, resting on the 
basement. They are overlain by Paleocene and Eocene chalks and radiolarites with cherts (Unit 2) that correspond to a well-bedded seismic unit up to $1500 \mathrm{~m}$ thick. Upper Oligocene to Middle Miocene chalks, and Middle Miocene to recent calcareous oozes (Unit 1) form the upper, more transparent seismic unit that is 500 to $600 \mathrm{~m}$ thick in our study area. Two major, regional unconformities delimit these three major seismic units, respectively: the mid-Paleocene/Lower Eocene unconformity and the Upper Eocene/Lower Oligocene unconformity. Figure 3 synthesises the geological data available from DSDP well sites 206, 207 and 208.

Diapirs were reported in the Fairway Basin (Auzende et al., 2000a; 2000c; Van de Beuque, 2003). These are circular features, $~ 3$ to $15 \mathrm{~km}$ wide, or form elongated ridges up to $50 \mathrm{~km}$ long. They do not appear to pierce through the seabed but some reach shallow sub-bottom depths. Diapiric material appears to arise from the basal sedimentary layer of the basin, presumably made of Upper Cretaceous sediments. The nature of this layer remains however debated. Diapirs could be salt diapirs or mud diapirs as the area was not favourable to salt deposition during Cretaceous times. Other larger diapir-like features could well be of volcanic origin (Lafoy et al., 1994; Exon et al.,

\section{High-Resolution seismic data: acquisition and processing details}

The surface seismic acquisition system was set up to acquire high resolution data (Figure 1). It uses a $3.3 \mathrm{~km}$ long streamer composed of 264 live channels, with a $12.5 \mathrm{~m}$ group interval and towed at $3 \mathrm{~m}$ immersion. The data were sampled at $1 \mathrm{~ms}$, and recorded using a SEAL lab. The source was composed of an array of 2 G-I guns and 3 mini G-I, with a total volume of $396 \mathrm{inch}^{3}$. It was operated at a nominal pressure of 140 bars, and immersion was set between 2.0 and $3.0 \mathrm{~m}$ in order to increase the high frequency content of the recorded signal, which was centered on $90 \mathrm{~Hz}$. Shooting interval was $25 \mathrm{~m}$, resulting in a maximum fold of 66 . The processing sequence applied to the high resolution seismic reflection data comprised: 1) SegD data input ; 2) geometry and CDP binning ; 3) shooting delay correction ; 4) frequency band pass filtering (15-230 Hz) ; 5) Spherical divergence corrections (water velocity) ; 6) velocity analysis ; 7) Normal Move Out corrections ; 8) good quality data (Figure 4 and 5). Penetration observed on processed data reaches about $2 \mathrm{~s}$ two 103 way timetravel (twt) (except when crossing the ridge) and vertical resolution is better than $10 \mathrm{~m}$.

The seismic signal was also recorded on 12 OBSs, that were deployed in 3 clusters, each cluster being composed of three OBSs deployed about $500 \mathrm{~m}$ apart from each other along the main 
shooting line (Z11-11) and one OBS offset by about $1 \mathrm{~km}$ in a direction perpendicular to the main shooting line. This acquisition scheme was designed to investigate the subsurface at 3 sites distinguished by their location with respect to the dome that affects the basement near the intersection between lines Z11-11 and Z11-12: Site 1 is located away from the basement dome; Site 2 is on its flank; and Site 3 at its apex. OBS data was recorded at $1 \mathrm{~ms}$ sampling rate. The processing sequence applied to the OBS records is summarised as follows: 1) shot time quality control and corrections (instrument skew, shooting delay, instrument recording delay); 2) data conversion to SegY format; 3) frequency band pass filtering (15-230 Hz); 4) picking of direct arrival times; 5) re-positioning (X, Y, Z) of OBS and determination of a best-fitting water velocity from the inversion of first arrival times; 6) spherical divergence corrections. The vertical resolution of the OBS hydrophone data, reported in this paper, is better than $10 \mathrm{~m}$, and thanks to a low noise level on the instruments, sediment penetration reaches $2 \mathrm{~s}$ twt.

\section{Analysis of ZoNeCo-11 high resolution seismic data}

Seismic line Z11-11 is centered on a basement dome, about $5 \mathrm{~km}$ wide (Figure 4). The basement reflector that delimits the dome appears to extend laterally to deep events marked as B on both sides of the dome. From the basement (above B events) to the seabed, the three main sedimentary units that have been proposed by Exon et al. (2007) are recognized :

$>$ Unit 3, about $300 \mathrm{~ms}$ thick at Site 1 (OBS 03), shows low amplitude, discontinuous reflectors. This unit disappears near the dome.

Unit 2 is composed of continuous, sub parallel strata. It is separated from Unit 3, underneath, by a strong positive polarity reflector, C. The top of the layer is marked by a reflector, hereafter named $\mathrm{RN}$, of strong amplitude and negative polarity. A strong reflector with positive polarity, RP, cuts across the strata of Unit 2. Away from the dome, RP is slightly chaotic. On the flanks, RP deepens, clearly cross cuts stratigraphic horizons, and sometimes coincides with these stratigraphic horizons for a short distance (Figure 4 and 5). $\mathrm{RP}$ is associated with a change in reflectivity, especially visible on the flanks of the intrusion, where reflectivity amplitudes are attenuated and frequency spectra are altered below RP with respect to the strata above.

Unit 1 appears as poorly reflective and affected by numerous sub-vertical faults (examples marked by F on Figure 4 and 5).

Reflectors RN and RP were further characterized using OBS data. Arrival times were 2D-inverted 
141 into velocity profiles using RAYINV software of Zelt and Smith (1992). In order to pick the arrival 142 times more easily, the seabed on OBS gathers was "flattened" using the re-positioned source and 143 receiver locations and the best-fitting water velocity to calculate a direct arrival time that was 144 subsequently subtracted from the arrival times for this configuration. Sediment velocity resolution 145 ranges from about $25 \mathrm{~m} / \mathrm{s}$ for shallow layers to about $80 \mathrm{~m} / \mathrm{s}$ for deep layers. Then, the OBS 146 reflectors were correlated with HR seismic line reflectors (RN and RP on Figure 6b). The results 147 clearly indicate that the P-wave velocity decreases with depth across $\mathrm{RN}$, while it increases across 148 RP (Figure 6b).

\section{DSDP stratigraphy.}

DSDP Site 208 on the Lord Howe Rise is of particular interest to this study because the stratigraphy revealed by the drilling data can be seismically tied up to the Fairway Basin (Figure 2). Drilling penetrated $320 \mathrm{~m}$ of recent foraminifera-bearing to Middle Miocene nannofossil oozes, then about $170 \mathrm{~m}$ of Middle Miocene to Middle Eocene nannofossil chalks (e.g. Burns et al., 1973d; Kennett et al., 1986). At $488 \mathrm{~m}$ below the seabed, the drilling reached the Eocene/Oligocene unconformity (Figure 3). Below the unconformity, siliceous sediments (radiolaria, diatoms, sponge spicules, silicoflagellata) were recovered, the matrix being composed of calcium carbonate. P-wave velocities and sediment densities at Site 208 decrease with depth across the Eocene / Oligocene unconformity because of the occurrence of siliceous sediments of increased sediment porosity (Burns et al., 1973a; 1973d). The oldest sediments drilled at DSDP Site 208 are Upper Cretaceous marine silico-clastic sediments.

Site 206 in the South New Caledonia Basin, penetrated the same sedimentary sequence (Figure 3). The Eocene / Oligocene unconformity was reached at $614 \mathrm{~m}$ below the seabed and the same P-wave velocity and density inversions were observed across this unconformity. Drilling data thus confirms the regional extent of the sedimentary units and unconformities.

\section{Linking DSDP Site 208 to the Fairway Basin: Regional Significance of RN and RP}

\subsection{Reflector RN}

172 To correlate the stratigraphic information from DSDP Site 208 to the reflectors documented in the 173 Fairway Basin, we used the multichannel seismic lines collected during AGSO/Surveys 206 and 174177 of R/V Rig Seismic (Figure 2) and all the 6-channel seismic lines that were collected in 1999 175 during the ZoNeCo-5 cruise of R/V L'Atalante and recently reprocessed for the purpose of the 
176

177

178

179

180

181

182

183

184

185

186

187

188

189

190

191

192

193

194

195

196

197

198

199

200

201

202

203

204

205

206

207

208

209

210

present work. See Appendix 1 in supplementary electronic data for more details on the correlation of seismic line s206-2 (FAUST-1 survey - (Lafoy et al., 1998) to DSDP 208 drill site (Burns et al., 1973d). At DSDP Site 208, a correspondence was established between the Eocene/Oligocene Unconformity (EOU) and a reflector documented on seismic line FAUST1-S206-2, which exhibits two remarkable characteristics: 1) it corresponds to a seismic phase inversion; 2) it separates a transparent layer with only one intra-Miocene reflector above, from a layer with numerous, well bedded sequences. This reflector, now associated to the EOU, can be tracked from the drill hole continuously to the Fairway Basin, following 2 different paths (Figure 2):

$>$ The northern path (Collot et al., 2008) : from DSDP Site 208 along line Faust1-S206-2 up to the intersection with FAUST1-S206-1; then along this line up to the crest and down to the eastern flank of Lord Howe Rise, where a reflector related to a seismic phase inversion is found at the base of a seismically transparent layer. The link to our study area in the Fairway Basin is then provided by seismic profiles ZoNeCo11-11, -10 and -09.

> The southern path: from DSDP Site 208 to the intersection with FAUST1-S206-3; then along this line up to the crest and down to the eastern flank of Lord Howe Rise (the identification in the basin is based on the same criteria as above : strong reflector with negative polarity at the base of a transparent layer) until line S 177- LHRNR-BA. This profile is very interesting because it is crosscut by numerous ZoNeCo5 profiles. The EOU was identified on all these crosscutting ZoNeCo5 profiles. Then, the link to our study area was provided by the ZoNeCo5-07 line (Figure 7) that connects to ZoNeCo-11 lines 09, 10 and 11.

In both cases, a clear correspondence is found between the EOU and reflector RN in the Fairway Basin.

In summary, RN: (1) has a negative polarity, (2) mimics approximately the sea floor but (3) does not cross-cut the sedimentary layers, (4) corresponds to the Eocene/Oligocene unconformity drilled at DSDP Site 208.

\subsection{Reflector RP}

Reflector RP, described above in section 4, is discontinuous and cannot be traced from the Fairway Basin to DSDP site 208. The BSR reflector that was identified by Auzende et al. (2000a) on the seismic lines collected during the $\mathrm{ZoNeCo} 5$ cruise, corresponds to RP (Figure 7 and 8). It is 
211 important to note that RP lies always below the Eocene/Oligocene Unconformity.

212 In summary, RP: (1) has a positive polarity (2) does not always mimic the sea floor (3) clearly 213 cross-cuts sedimentary layers, (4) is always situated deeper than the Eocene/Oligocene 214 unconformity (RN), (5) corresponds to the BSR previously described by Auzende et al. (2000a) 215 from ZoNeCo 5 seismic data.

\section{Heat flow constraints}

Heat flow data (Figure 9 and Table 1) were collected at 5 different sites in the study area in February 2006 with R/V Marion Dufresne (Foucher and scientific party, 2006). Sediment temperature at each site was measured at up to 7 different depths in the sub-bottom by means of thermistor temperature sensors attached on outriggers to a $18 \mathrm{~m}$ long lance of the CALYPSO gravity corer of the R/V Marion Dufresne. Sediment equilibrium temperatures were extrapolated from thermal transients recorded for $6-10 \mathrm{mn}$ following penetration. Thermal conductivity was measured by the needle probe technique on the recovered core at each heat flow measurement site. The relative accuracy of temperature measurements is estimated to be better than $0.01{ }^{\circ} \mathrm{C}$ (for each temperature sensor with respect to other sensors) and $5 \%$ for conductivity measured on cores.

Two sites (MD06-3022 and MD06-3023) are located along seismic profile ZoNeCo11-11. At the apex of the basement high (site MD06-3022), the measured heat flux is $54 \mathrm{~mW} / \mathrm{m}^{2}$. Less than 2.5 $\mathrm{km}$ away to the south (site MD06-3023), the heat flux is $49 \mathrm{~mW} / \mathrm{m}^{2}$. The three remaining sites are 232 located along seismic profile ZoNeCo11-09. At these sites, the layer above the Eocene-Oligocene 233 Unconformity appears to be crosscut by normal faults along which fluid escapes are suspected. Heat flux was measured to be 64,53 and $49 \mathrm{~mW} / \mathrm{m}^{2}$ at sites MD06-3026, 3027 and 3028 respectively.

The above heat flow data provide the first available information on the thermal regime of the Fairway Basin. The heat flow values are fairly consistent, ranging from 49 to $64 \mathrm{~mW} / \mathrm{m}^{2}$. The spatial variability could be explained by heat flow refraction or fluid flow effects. The higher heat flow of $54 \mathrm{~mW} / \mathrm{m}^{2}$ at the apex of the basement ridge at site MD06-3022, with respect to the slightly lower value of $49 \mathrm{~mW} / \mathrm{m}^{2}$ measured at site MD06-3023 on the flank of this ridge, could be a result of heat flow refraction from low thermal conductivity sediments surrounding the ridge to the higher thermal conductivity body that the ridge is likely to be. On the other hand, the variable heat flow values of $49-64 \mathrm{~mW} / \mathrm{m}^{2}$ at sites MD06-3026, 3027 and 3028 may indicate disturbances to the conductive thermal regime due to fluid advection along normal faults observed on the seismic section Z11-09. 
247 Based on these data, the gas hydrate z-T stability field was calculated using the method described in 248 Sultan et al. (2004). Thermal conductivity was measured on cores taken at heat flow stations. 249 Measurements indicate a value of $\sim 1.0 \mathrm{WK}^{-1} \mathrm{~m}^{-1}$ at seabed. For deeper sediments, thermal conductivity was estimated from:

$$
\lambda=\lambda_{\mathrm{w}}^{(1-\phi)} \cdot \lambda_{\mathrm{m}}^{\phi}
$$

where $\lambda_{\mathrm{w}}$ is the thermal conductivity of water $\left(0.7 \mathrm{WK}^{-1} \mathrm{~m}^{-1}\right), \lambda_{\mathrm{m}}$ is the thermal conductivity of the sediment matrix and $\phi$ is the porosity. DSDP Sites 206, 207 and 208 data showed an upper sedimentary sequence made of calcareous ooze, from Oligocene to Recent, above the EoceneOligocene unconformity, and a mean porosity of $60 \%$. Taking $\lambda_{\mathrm{m}}=3.0 \mathrm{WK}^{-1} \mathrm{~m}^{-1}$, a conventional value for calcite, and $\phi=0.6$, an estimated value of the thermal conductivity, $\lambda$, is $1.25 \mathrm{WK}^{-1} \mathrm{~m}^{-1}$. Allowing for some uncertainty in this value and its distribution with depth, the thermal conductivity was assumed to be constant with depth and ascribed to vary between 1.0 and $1.5 \mathrm{WK}^{-1} \mathrm{~m}^{-1}$. We have also assumed that: 1) heat transfer in the sediment column is purely conductive; 2) sediment pore water salinity is constant and equal to $\sim 34.9 \%$ (Jean-Luc Charlou, pers. comm. 2008); 3) hydrate is from methane gas only. The depths of the base of the gas hydrate stability zone (GHSZ) at each heat flow measurement site was computed using the HYSFA Code (Sultan et al., 2004). Results are listed in Table 2. At all sites, except for MD06-2328, reflector RP lies deeper than what is considered to be an acceptable range for the base of the methane gas hydrate stability zone. Heat flow data alone cannot be considered as a proof per se, as other sources of uncertainties - such as gas composition or depth determination - may occur. If the clathrate gas were made of hydrocarbon gases heavier than methane, the theoretical BSR could lie deeper than expected. Also, errors in depth conversion cannot be ruled out, however the quality of the high resolution data that we use and the availability of velocity determinations based on OBSs (Figure 6) are such that uncertainties appear unlikely to significantly alter our conclusions.

\section{Discussion: nature of the BSR in the Fairway Basin}

Here, we discuss the different hypotheses retained by Exon et al. (2007) to explain the occurrence of the BSR (our RP reflector), mainly: gas or gas hydrate versus diagenetic front. A BSR at the top of a gas hydrate layer has been observed on the Nankai margin, offshore Japan (Nouze et al., 2004), where coarse sediment layers contain large amounts of gas hydrate (up to $70-80 \%$ of the pore space). As illustrated by this example, a significant content of hydrate is necessary to create an impedance contrast strong enough to generate a clear reflector associated with the presence of hydrate, and thus a significant amount of gas is required in the sediment to form this hydrate. The 
BSR in the Fairway Basin is present extensively (Auzende et al., 2000a), but there has been so far no evidence of a high content of potentially-hydrate-forming gas (hydrocarbons) in cores taken in 283 the Fairway Basin along ZoNeCo-11 study site (Jean-Luc Charlou, personal communication). 284 Furthermore, should the top of a gas hydrate layer be detected by a BSR, one would expect its bottom to be observed as well, as this is the case in the Nankai margin (e.g. Nouze et al., 2004). Another strong argument against the hydrate-related BSR hypothesis arises from the heat flow results presented in this paper. If hydrate occurrences in the Fairway Basin were to be dominated by methane hydrate, the BSR would lie too deep below the seabed to lie in the stability field of a methane hydrate. Moreover, the large lateral extent of the BSR within the Fairway Basin over more than 70,000 km2, mapped with the ZoNeCo-5 survey by Auzende et al. (2000a), is unusual for gashydrate BSR and much more typical for opal A / CT BSR. Note that Exon et al. (2004a; 2007) identified a similar BSR farther south (around $31^{\circ} \mathrm{S}$ ) in the southern Fairway Basin, located on the flanks of the East Lord Howe Spur (profiles 10 and 11 of seismic survey s232). This further confirms the regional extent of the BSR and reinforces the argument of a non-gas-hydrate related BSR.

On the other hand, Exon et al. (2007) considered that if the BSR were of diagenetic origin, «it could only have been generated by an upward moving, silica-rich diagenetic front ». These authors rejected the hypothesis of an Opal-A / Opal-CT transition because, according to their interpretation, the BSR would lie above the Eocene/Oligocene unconformity, hence in carbonates almost devoid of silica according to DSDP Site 208 data. Our interpretation for the position of the Eocene/Oligocene unconformity in the Fairway Basin differs from that proposed by Exon et al. (2007). We have shown that the BSR indeed lies within Eocene siliceous sediments. Thus the major argument against the hypothesis no longer holds. On the contrary, the recovery in mid-Eocene sediments at DSDP Site 208 of a piece of porcelanite, made from cristobalite (i.e. Opal-CT) resulting from recrystallisation of biogenic silica, gives support to the interpretation of the BSR as an impedance contrast at the Opal-A / Opal-CT transition.

The Opal-A / Opal-CT transition has been widely discussed in the literature. Opal-A, which was defined by Jones and Segnit (1971), is a siliceous ooze resulting from the dissolution of siliceous organisms tests. With the burying with sediments, pressure and temperature increase and a dissolution re-precipitation reaction converts opal-A into opal-CT. This reaction generates an interface between the two types of opal with an increase in density and a decrease in porosity and permeability, involving an impedance contrast strong enough to create a reflector with positive polarity (e.g. Ramsay, 1971; Hempel et al., 1989; Lee et al., 2003). Temperature is a main parameter 
controlling the Opal-A / Opal-CT transition. However, this diagenetic process is also influenced by pressure, time (related to the burying of the siliceous sediments), nature of the surrounding rocks (e.g. carbonates increase the reaction rate), and interstitial waters (e.g. Hein et al., 1978; Williams and Crerar, 1985; Kuramoto et al., 1992; Nobes et al., 1992; Davies, 2005). BSRs have been interpreted as an opal-A / opal-CT transformation in several areas of the world including Monterey Formation in California (Isaacs, 1982), Bermuda Rise (Thein and von Rad, 1987), the Antarctic basin (Botz and Bohrmann, 1991), the Japan Sea (Kuramoto et al., 1992), the Norwegian Sea (Henrich, 1989; Berndt, 2004), the Faeroe-Shetland basin (Davies and Cartwright, 2002), New Zealand (Lynne and Campbell, 2004), the Southwest Indian ridge (Gerland et al., 1997). Volpi et al. (2003) reported observations of a diagenetic BSR related to the Opal-A/Opal-CT transformation on the Pacific margin of the Antarctic Peninsula. The BSR clearly crosscuts the stratigraphy and divides the sedimentary layer into a strong reflectivity zone (above) and a low reflectivity zone (below) (Figure 10b). One will note that this change in reflectivity across the BSR at the Antarctic site shares strong similarities with our own observations on ZoNeCo-11 seismic profiles (Figure 10a). Also, as noted by Volpi et al. (2003), the diagenetic alteration of opal-A to opal-CT causes a dramatic reduction of intra- and interskeletal porosity, resulting in overpressuring in altered sediments and settlement of channelised fluid escape features from these sediments to the seabed. Davies and Cartwright (2002) estimated that the volume reduction associated with the Opal-A / Opal-CT transformation could be 30-40\%, an amount large enough to account for the developpement of a polygonal fault system. Such a fault system may have $\square$ rench $\square$ ia within the sedimentary layers above the BSR in the Fairway Basin as suggested by the complex network of small-offset vertical faults visible on our 2D seismic lines (Figure 4 and 5). All these observations favour an interpretation of the BSR in the Fairway Basin as related to an Opal-A / Opal-CT transition. Finally, on ZoNeCo-11 line Z11-11, the BSR appears to deepen on the flanks of the basement dome with respect to a bump in the sedimentary layers (Figure 5). A downward shift in the Opal A - Opal CT transition could result from a pressure decrease due to faulting or a temperature distribution altered by the formation of the basement dome.

\section{Conclusion}

The present work sheds light on the stratigraphy of the Fairway Basin as well as the nature of its BSR. Two major reflectors, RN and RP, were identified on the high-resolution lines, and correlated to DSDP drilling data. RN is a negative polarity reflector, mimicking approximately the seafloor. According to our interpretation, $\mathrm{RN}$ is a regional reflector that marks the Eocene/Oligocene unconformity. The negative polarity of $\mathrm{RN}$ is accounted for by low Vp velocity and density of 
351 silica-rich Eocene sediments with respect to overlying Oligocene carbonate oozes. RP is a positive 352 polarity reflector, crosscutting sediment strata. Both seismic and heat flow data tend to support the 353 interpretation of this reflector as a diagenetic front (Opal-A / opal-CT transition) rather than a 354 methane-hydrate BSR.

\section{Acknowledgments :}

The ZoNéco-11 and ZoNéCo-12 cruises were conducted within the framework of the ZoNéCo program (Assessment of living and non-living resources of New Caledonia EEZ) funded by ADECAL (Agency for the Economic development of New Caledonia). We thank the following people and organizations: IFREMER, IPEV and the Service Géologique de Nouvelle-Calédonie; shipboard party of cruises ZoNéCo-11 and ZoNéCo-12 cruises ; officers and crew of R/V l'Atalante and R/V Marion Dufresne. We are also grateful to G. Bernardel from Geoscience Australia (former AGSO) for the coowned FAUST data New Caledonia / Australia. Special thanks to Nabil Sultan for providing the HYSFA Code; to Yvon Balut (IPEV); to François Harmegnies for collecting the heat flow data and to Jean-Luc Charlou for communicating unpublished data collected during the ZoNéco-12 Cruise. Maps are produced with the Generic Mapping Tool 4.2.1 (http://gmt.soest.hawaii.edu), seismic data was processed with CGG-Geocluster and IFREMER-Sisbise. 
References

Auzende, J.-M., Van de Beuque, S., Dickens, G., François, C., Lafoy, Y., Voutay, O., Exon, N., 2000a. Deep sea diapirs and bottom simulating reflector in Fairway basin (SW Pacific). Marine Geophysical Researches 21, 579-587.

Auzende, J.-M., Van de Beuque, S., Regnier, M., Lafoy, Y., Symonds, P., 2000b. Origin of the New Caledonian ophiolites based on a French-Australian Seismic Transect. Marine Geology 162(2-4), 225-236.

Auzende, J.M., Beneton, G., Dickens, G., Exon, N., Francois, C., Hodway, D., Juffroy, F., Lafoy, Y., Leroy, A., van de Beuque, S., Voutay, O., 2000c. Mise en évidence de diapirs mésozoiques sur la bordure orientale de la ride de Lord Howe (Sud-Ouest Pacifique) : campagne ZoNeCo 5. Comptes rendus de l'Académie des sciences, Série II, Sciences de la terre et des planètes 330(3), 209-215.

Bernardel, G., 1999. Preliminary results from AGSO Law of the Sea Cruise 206: an australian/french collaborative deep seismic marine survey in the Lord Howe Rise/New Caledonia region. Australian Geological Survey Organisation record 1994/14, 37.

Berndt, C.B., S.;Clayton,T.;Mienert, J.;Saunders, M., 2004. Seismic character of bottom simulating reflectors: examples from mid-Norwegian margin. Marine and Petroleum Geology 21, 723733.

Botz, R., Bohrmann, G., 1991. LOW-TEMPERATURE OPAL-CT PRECIPITATION IN ANTARCTIC DEEP-SEA SEDIMENTS - EVIDENCE FROM OXYGEN ISOTOPES. Earth and Planetary Science Letters 107(3-4), 612-617.

Burns, R.E., Andrews, J.E., Van der Lingen, G.J., Andrews, J.E., Churkin, M., Jr., Davies, T.A., Dumitrica, P., Edwards, A.R., Galehouse, J.S., Kennett, J.P., Packham, G.H., 1973a. Regional aspects of deep sea drilling in the Southwest Pacific, Lithostratigraphy of Eight Drill Sites in the South-west Pacific. Preliminary Results of the Deep Sea Drilling Project 21.

Burns, R.E., Andrews, J.E., van der Lingen, G.J., Churkin, M., Jr., Galehouse, J.S., Packham, G., Davies, T.A., Kennett, J.P., Dumitrica, P., Edwards, A.R., Von Herzen, R.P., 1973b. Site 206. Initial Reports of the Deep Sea Drilling Project - Leg 21(Suva, Fiji to Darwin, Australia Nov. 1971-Jan. 1972), 103-195.

Burns, R.E., Andrews, J.E., van der Lingen, G.J., Churkin, M., Jr., Galehouse, J.S., Packham, G., Davies, T.A., Kennett, J.P., Dumitrica, P., Edwards, A.R., Von Herzen, R.P., 1973c. Site 207. Initial Reports of the Deep Sea Drilling Project - Leg 21(Suva, Fiji to Darwin, Australia Nov. 1971-Jan. 1972), 197-269.

Burns, R.E., Andrews, J.E., van der Lingen, G.J., Churkin, M., Jr., Galehouse, J.S., Packham, G., Davies, T.A., Kennett, J.P., Dumitrica, P., Edwards, A.R., Von Herzen, R.P., 1973d. Site 208. Initial Reports of the Deep Sea Drilling Project - Leg 21(Suva, Fiji to Darwin, Australia Nov. 1971-Jan. 1972), 271-331.

Collot, J., Géli, L., Lafoy, Y., Vially, R., Cluzel, D., Klingelhöefer, F., Nouzé, H., 2008. Tectonic history of northern New Caledonia Basin from deep offshore seismic reflection: Relation to late Eocene obduction in New Caledonia, southwest Pacific. Tectonics 27(TC6006), doi:10.1029/2008TC02263.

Davies, R.J., 2005. Differential compaction and subsidence in sedimentary basins due to silica diagenesis: A case study. Geological Society of America Bulletin 117(9-10), 1146-1155.

Davies, R.J., Cartwright, J., 2002. A fossilized Opal A to Opal C/T transformation on the northeast Atlantic margin: support for a significantly elevated Palaeogeothermal gradient during the Neogene? Basin Research 14(4), 467-486.

Exon, N., Dickens, G., Auzende, J.-M., Lafoy, Y., Symonds, P., van de Beuque, S., 1998. Gaz hydrates and free gas on the Lord Howe Rise, Tasman Sea. Petroleum Exploration Society of Australia Journal 26, 148-158. 
Exon, N., Hill, P., Lafoy, Y., Fellows, M., Perry, K., Mitts, P., Howe, R., Chaproniere, G.C.H., Dickens, G., Ussler, B., Paull, C.K., 2004a. Geology of the Fairway and New Caledonia basins in the Tasman Sea: sediment, pore water, diapirs and bottom simulating reflectors (Franklin cruise FR9/01 and Geoscience Australia Survey 232). Geoscience Australia Record 2004(26), 1-112.

Exon, N., Lafoy, Y., Hill, P.J., Dickens, G., Pecher, I., 2007. Geology and petroleum potential of the Fairway Basin in the Tasman Sea. Australian Journal of Earth Sciences 54, 629-645.

Exon, N., Quilty, P., Lafoy, Y., Crawford, A.J., Auzende, J.-M., 2004b. Miocene volcanic seamounts on northern Lord Howe Rise: lithology, age and origin. Australian Journal of Earth Sciences 51, 291-300.

Foucher, J.P., Scient.party, 2006. Rapport de la campagne AUSFAIR/ZoNéCo-12, à bord du N/O Marion Dufresnes. 12-26 Février 2006.

Gaina, C., Mueller, D.R., Royer, J.-Y., Stock, J., Hardebeck, J.L., Symonds, P., 1998. The tectonic history of the Tasman Sea: a puzzle with 13 pieces. Journal of Geophysical Research - Solid Earth 103(6), 12,413-12,433.

Gerland, S., Kuhn, G., Bohrmann, G., 1997. Physical properties of a porcellanite layer (Southwest Indian Ridge) constrained by geophysical logging. Marine Geology 140(3-4), 415-426.

Hayes Dennis, E., Ringis, J., 1973. Seafloor Spreading in the Tasman Sea. Nature (London) 244(5408), 454-458.

Hein, J.R., Scholl, D.W., Barron, J.A., Jones, M.G., Miller, J., 1978. DIAGENESIS OF LATE CENOZOIC DIATOMACEOUS DEPOSITS AND FORMATION OF BOTTOM SIMULATING REFLECTOR IN SOUTHERN BERING SEA. Sedimentology 25(2), 155181.

Hempel, P., Mayer, L., Taylor, E., Bohrmann, G., Pittenger, A., 1989. The influence of biogenic silica on seismic lithostratigraphy at ODP sites 641 and 643, Eastern Norwegian Sea. Proceedings of the Ocean Drilling Program, Scientific Results, 104.

Henrich, R., 1989. Diagenetic environments of authigenic carbonates and opalCT crystallization in lower Miocene to upper Oligocene deposits of the Norwegian Sea (ODP Site 643, Leg 104). Proceedings of the Ocean Drilling Program, Scientific Results, 104.

Isaacs, C.M., 1982. INFLUENCE OF ROCK COMPOSITION ON KINETICS OF SILICA PHASE-CHANGES IN THE MONTEREY FORMATION, SANTA-BARBARA AREA, CALIFORNIA. Geology 10(6), 304-308.

Jones, J.B., Segnit, E.R., 1971. The nature of Opal I. Nomenclature and constituent phase. Journal of the Geological Society of Australia 18(1), 57-68.

Kennett, J.P., von der Borch Christopher, C., Baker Paul, A., Barton Charles, E., Boersma, A., Caulet Jean, P., Dudley Walter, C., Jr., Gardner James, V., Jenkins, D.G., Lohman William, H., Martini, E., Merrill Russell, B., Morin Roger, H., Nelson Campbell, S., Robert, C., Srinivasan, M.S., Stein, R., Takeuchi, A., Blakeslee Jan, H., 1986. Site 587. Initial Reports of the Deep Sea Drilling Project - Leg 90(Noumea, New Caledonia, to Wellington, New Zealand, December 1982-January 1983 Part 1), 115-138.

Klingelhoefer, F., Lafoy, Y., Collot, J., Cosquer, E., Géli, L., Nouzé, H., Vially, R., 2007. Crustal structure of the basin and ridge system west of New Caledonia (southwest Pacific) from wide-angle and reflection seismic data. Journal of Geophysical Research - Solid Earth 112(B11102).

Kuramoto, S., Tamaki, K., Langseth, M.G., Nobes, D.C., Tokuyama, H., Pisciotto, K.A., Taira, A., 1992. Can opalA/opalCT BSR be an indicator of the thermal structure of the Yamamoto basin. Japan Sea? Proceedings of the Ocean Drilling Program, Scientific Results, 127/128.

Lafoy, Y., Géli, L., Klingelhoefer, F., Vially, R., Sichler, B., Nouzé, H., 2005. Discovery of continental stretching and oceanic spreading in the Tasman sea. Eos Transactions of American Geophysical Union 86(10), 101+104-105.

Lafoy, Y., Pelletier, B., Auzende, J.M., Missègue, F., Mollard, L., 1994. Tectonique compressive cénozoïque sur les rides de Fairway et Lord Howe, entre Nouvelle Calédonie et Australie. 
Comptes rendus de l'Académie des sciences, Série II, Sciences de la terre et des planètes 319, 1063-1069.

Lafoy, Y., van de Beuque, S., Missegue, F., Nercessian, A., Bernadel, G., 1998. Campagne de sismique multitrace entre la marge Est Australienne et le Sud de l'arc des NouvellesHébrides - Rapport de la campagne RIG SEISMIC 206 (21 avril - 24 mai 1998) Programme FAUST.

Lee, G.H., Kim, H.J., Jou, H.T., Cho, H.M., 2003. Opal-A/opal-CT phase boundary inferred from bottom-simulating reflectors in the southern South Korea Plateau, East Sea (Sea of Japan). Geophysical Research Letters 30(24).

Lynne, B.Y., Campbell, K.A., 2004. Morphologic and mineralogic transitions from opal-A to opalCT in low-temperature siliceous sinter diagenesis, Taupo Volcanic Zone, New Zealand. Journal of Sedimentary Research 74(4), 561-579.

Nobes, D.C., Murray, R.W., Kuramoto, S., Pisciotto, K.A., Holler, H., 1992. Impact of silica diagenesis on physical property variations. Proceedings of the Ocean Drilling Program, Scientific Results, 127/128.

Nouze, H., Henry, P., Noble, M., Martin, V., Pascal, G., 2004. Large gas hydrate accumulations on the eastern Nankai Trough inferred from new high-resolution 2-D seismic data. Geophysical Research Letters 31(13).

Nouzé, H., Lafoy, Y., Géli, L., Klingelhoefer, F., party, Z.c., 2005. First results of a high resolution seismic study of a Bottom Simulating Reflector in the Fairway Basin, offshore New Caledonia, Fifth International Conference on Gas Hydrates (ICGH 5), Trondheim, Norway.

Pecher, I.A., 2004. Waveform inversion applied to a bottom simulating reflection on the eastern Lord Howe Rise. Institute of Geological and Nuclear Sciences, Science report

Ramsay, A.T.S., 1971. OCCURRENCE OF BIOGENIC SILICEOUS SEDIMENTS IN ATLANTIC OCEAN. Nature 233(5315), 115-125.

Ramsay, D.C., Herzer, R.H., Barnes, P.M., 1997. Continental shelf definition in the Lord Howe Rise and Norfolk Ridge regions: law of the sea survey 177, Part 1 - preliminary results. Australian Geological Survey Organisation record 1997/54.

Ravenne, C., De Broin, C.E., Dupont, J., Lapouille, A., Launay, J., 1977. New Caledonia basinFairway Ridge: structural and sedimentary study, International Symposium on Geodynamics in the Southwest Pacific. Technip, Nouméa (New Caledonia), pp. 145-154.

Sultan, N., Cochonat, P., Foucher, J.P., Mienert, J., 2004. Effect of gas hydrates melting on seafloor slope instability. Marine Geology 213(1-4), 379-401.

Thein, J., von Rad, U., 1987. Silica diagenesis in continental rise and slope sediments off eastern North America (Sites 603 and 605, Leg 93; Sites 612 and 613, Leg 95). Initial Reports of the Deep Sea Drilling Project, 95, Washington (U.S. Govt. Printing Office).

Van de Beuque, S., 2003. Geological framework of the Northern Lord Howe Rise and adjacent areas. Geoscience Australia Record 2003, 1-116.

Van de Beuque, S., Auzende, J.-M., Lafoy, Y., Bernardel, G., Nercessian, A., Regnier, M., Symonds, P., Exon, N., 1998. Transect sismique continu entre l'arc des Nouvelles-Hebrides et la marge orientale de l'Australie: programme FAUST (French Australian Seismic Transect). Comptes Rendus de l'Académie des Sciences, Série 2 327(11), 761-768.

Volpi, V., Camerlenghi, A., Hillenbrand, C.D., Rebesco, M., Ivaldi, R., 2003. Effects of biogenic silica on sediment compaction and slope stability on the Pacific margin of the Antarctic Peninsula. Basin Research 15(3), 339-363.

Weissel, J.K., Hayes, D.E., 1972. Evolution of the Tasman Sea reappraised. Earth and Planetary Science Letters 36, 77-84.

Williams, L.A., Crerar, D.A., 1985. SILICA DIAGENESIS - GENERAL MECHANISMS. Journal of Sedimentary Petrology 55(3), 312-321.

Zelt, C.A., Smith, R.B., 1992. SEISMIC TRAVELTIME INVERSION FOR 2-D CRUSTAL VELOCITY STRUCTURE. Geophysical Journal International 108(1), 16-34. 
TABLES

\begin{tabular}{|c|c|c|c|c|c|c|c|c|c|c|c|c|}
\hline Station & Seismic & Latitude & Longitude & Depth & BWT & Pen. & \multirow{2}{*}{\multicolumn{2}{|c|}{$\frac{\text { Grad T }}{{ }^{\circ} \mathrm{C} / \mathrm{km}}$}} & \multirow{2}{*}{\multicolumn{2}{|c|}{$\begin{array}{c}\text { Cond. } \\
\mathrm{Wm}^{-1} \mathrm{~K}^{-1}\end{array}$}} & \multicolumn{2}{|c|}{ HF } \\
\hline MD06- & Correspondance & $\mathbf{S}$ & $\mathbf{E}$ & $\mathbf{m}$ & ${ }^{\circ} \mathrm{C}$ & (m) & & & & & & $\mathrm{m}^{2}$ \\
\hline $3022-1$ & $\begin{array}{c}\text { Z11-11 } \\
\text { CDP3410 }\end{array}$ & $23^{\circ} 12.11$ & $163^{\circ} 27.94$ & 2294 & 1.976 & 19.4 & 54.2 & \pm 1.13 & 0.99 & \pm 0.04 & 53.82 & \pm 1.13 \\
\hline $3022-2$ & $\begin{array}{c}\text { Z11-11 } \\
\text { CDP3410 }\end{array}$ & $23^{\circ} 12.10$ & $163^{\circ} 27.89$ & 2289 & 1.958 & 19.4 & 55.2 & \pm 2.56 & & & 54.81 & \pm 2.56 \\
\hline $3023-1$ & $\begin{array}{c}\text { Z11-11 } \\
\text { CDP2840 }\end{array}$ & $23^{\circ} 13.25$ & $163^{\circ} 29.65$ & 2344 & & 18.4 & 47.4 & \pm 1.12 & 1.05 & \pm 0.04 & 49.61 & \pm 1.12 \\
\hline $3023-2$ & $\begin{array}{c}\text { Z11-11 } \\
\text { CDP2840 }\end{array}$ & $23^{\circ} 13.24$ & $163^{\circ} 29.65$ & 2344 & 1.910 & 18.4 & 46.5 & \pm 1.11 & & & 48.66 & \pm 1.11 \\
\hline $3026-1$ & $\begin{array}{c}\text { Z11-9-2 } \\
\text { CDP3510 }\end{array}$ & $23^{\circ} 56.26$ & $163^{\circ} 27.72$ & 2717 & 1.835 & 13.9 & 65.8 & \pm 4.62 & 0.99 & \pm 0.03 & 64.40 & \pm 4.62 \\
\hline $3026-2^{*}$ & $\begin{array}{c}\text { Z11-9-2 } \\
\text { CDP3510 }\end{array}$ & $23^{\circ} 56.24$ & $163^{\circ} 27.67$ & 2717 & 1.8185 & $\begin{array}{c}6.50 \\
\text { (bent) }\end{array}$ & 77.1 & \pm 4.09 & & & 75.46 & \pm 4.09 \\
\hline 3027 & $\begin{array}{c}\text { Z11-9-1 } \\
\text { CDP5701 }\end{array}$ & $24^{\circ} 40.61$ & $163^{\circ} 36.14$ & 2720 & 1.820 & 14.0 & 52.6 & \pm 2.94 & 1.00 & \pm 0.03 & 52.65 & \pm 2.94 \\
\hline $3028-1$ & $\begin{array}{c}\text { Z11-9-1 } \\
\text { CDP5015 }\end{array}$ & $24^{\circ} 45.20$ & $163^{\circ} 36.95$ & 2716 & 1.823 & 14.0 & 49.0 & \pm 2.53 & 1.02 & \pm 0.03 & 49.79 & \pm 2.53 \\
\hline $3028-2$ & $\begin{array}{c}\text { Z11-9-1 } \\
\text { CDP5015 }\end{array}$ & $24^{\circ} 45.17$ & $163^{\circ} 36.98$ & 2716 & 1.818 & 14.0 & 47.7 & \pm 1.89 & & & 48.47 & \pm 1.89 \\
\hline
\end{tabular}

Table 1 : Heat flow measurements collected during the AUSFAIR/ZoNeCo-12 after Foucher et al. (2006) in the French EEZ. Two measurements were made at each site (except MD06-3023) by multiple entry into the sediments using the PO-GO like technique. The thermal measurement at site MD06-3026-2 is not reliable, as the corer bent.

\begin{tabular}{|c|c|c|c|c|c|}
\hline Site (MD06-) & water depth $(\mathrm{m})$ & Z_RN & Z_RP & Z_min & Z_max \\
\hline 3022 & 2294 & 2862 & 3067 & 2633 & 2826 \\
\hline 3023 & 2344 & 2968 & 3172 & 2727 & 2925 \\
\hline 3026 & 2717 & 3292 & 3345 & 3023 & 3185 \\
\hline 3027 & 2720 & 3305 & 3374 & 3090 & 3303 \\
\hline 3028 & 2716 & 3030 & 3099 & 3125 & 3340 \\
\hline
\end{tabular}

Table 2: $z \_R N$ and $z \_R P$ are the depth below sea level of reflectors RN and RP at each heat flow 538 measurement site. The depth below sea level of the base of the gas hydrate stability zone was calculated with the HYSFA code described in Sultan et al. (2004), assuming a constant thermal conductivity in the sediment column: $Z_{-}$min and $Z \_$max aree for thermal conductivity equal of 1.0

$541 \mathrm{Wm}^{-1} \mathrm{~K}^{-1}$ and $1.5 \mathrm{Wm}^{-1} \mathrm{~K}^{-1}$ respectively.

\section{Figure captions}

546 Figure 1: General location map of the North and Central Fairway Basin. The multichannel seismic 
lines collected in 2004 during the ZoNeCo-11 Cruise of R/V L'Atalante are indicated in red, the High Resolution Survey area being circled in blue. Yellow dots indicate heat flow measurements collected in 2006 during the ZoNeCo-12 cruise of R/V Marion Dufresne. The green line delineates the area surveyed in 1999 during the ZoNeco-5 cruise of R/V L'Atalante.

Inset shows the implementation of the High Resolution Seismic lines (Z11-11 to Z11-14) that were recorded during the ZoNeCo-11 cruise. The seismic signal was also recorded on 12 OBSs, that were deployed in 3 clusters, each cluster being composed of three OBSs deployed about 500m apart from each other along the main shooting line (Z11-11) and

Figure 2: Location map of the existing seismic lines that were used in this study. Location of DSDP drill hole sites is also indicated. The zoom shows the paths that were followed to track the Eocene-Oligocene Unconformity from DSDP Site 208 to the High Resolution Survey Area in the Fairway Basin. The northern path (Collot et al, 2008) is underlined in yellow. The southern path is underlined in green (see text).

Figure 3: Stratigraphy at DSDP sites 206, 207 and 208 (e.g. Burns et al., 1973d; 1973c; 1973b). Modified from Collot et al. (2008) Location is shown on Figure 2.

Figure 4: Zonéco 11, High Resolution line 11 (Z11-11) shot in 2004 during the ZoNeCo-11 cruise. OBS locations are indicated, as well as heat flow sites (MD06-3023 and MD06-3022) (after Foucher et al, 2006). Faults cutting the upper sedimentary layer are shown by arrows marked with letter F. Reflectors B, C, RN and RP are described in the text.

Figure 5: Zonéco 11, High Resolution line 13 (Z11-13). F stands for « fault ». In the southwest part of the section, note the strange behaviour of RN: while RN shallows, RP deepens and cross-cuts sediments layers.

Figure 6: 6a) Data from OBS 02 (site 1). Direct arrivals from the seabottom are flattened with the best fitting water velocity; 6b) High-resolution seismic reflection section and vertical velocity profile below OBS 02 , based on refraction data. Note that $\mathrm{RN}$ corresponds to a 
decrease in velocity downwards, while RP is associated to an increase in velocity.

584 Figure 7: Seismic line 07, collected in 1999 during the ZoNeCo-5 cruise of R/V L'Atalante with a 6-channel streamer. After reprocessing, it clearly appears that RN corresponds to a discordance. Some truncations (T) are indicated. This line is superimposed with the Z1109 profile of ZoNeCo-11. The ship tracks are such that the reflectors RN and RP that were identified in the ZoNeco-11 high resolution seismic lines can be followed over the Central Fairway Basin using ZoNeCo-5 lines.

Figure 8: ZoNeCo 5, line 11, showing that RN corresponds to a seismic discordance ( $\mathrm{T}$ stands for «truncations »). In the southern part (left) RN has an inverse polarity (with respect to the water bottom reflection polarity). Whereas in the northern part (right) $\mathrm{RN}$ lies at the top

Figure 10: a) zoom of the north-west part of the Z11-11 profile showing that RP divides the sedimentary layers into a strong reflectivity zone (above) and a low reflectivity zone (below); b) Seismic section from the Pacific margin of the Antarctic Peninsula, after (Volpi et al, 2003). Note the reflectivity changes across the diagenetic BSR related to an opalA/opal-CT. Also note similarities between both sections. 


\section{Zoneco11 \\ - Heat flow (Zoneco12) \\ - BSR extension from Zoneco5 \\ O High resolution selsmic area}
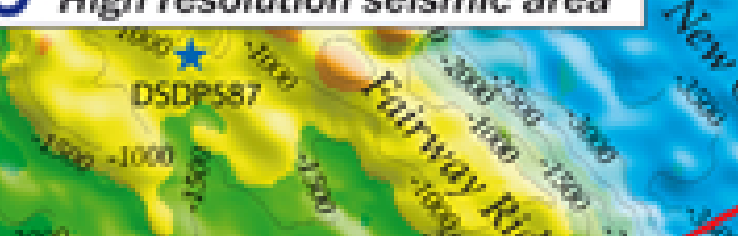

$-1000$

- $100,+4$

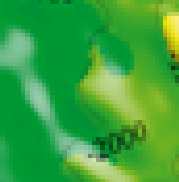

th $-1,+4$
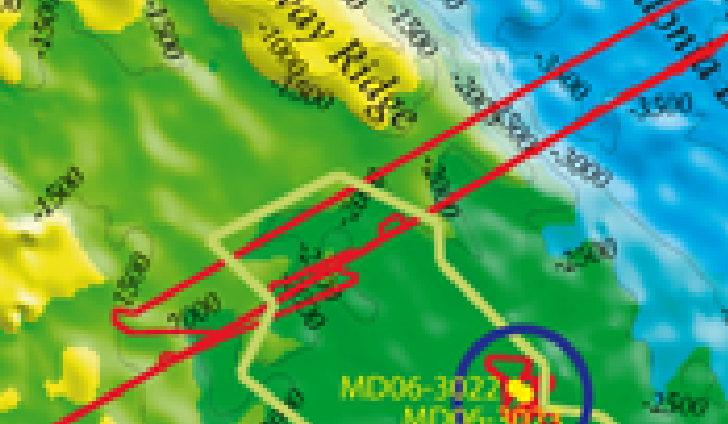
rent $5=$

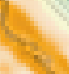

whe
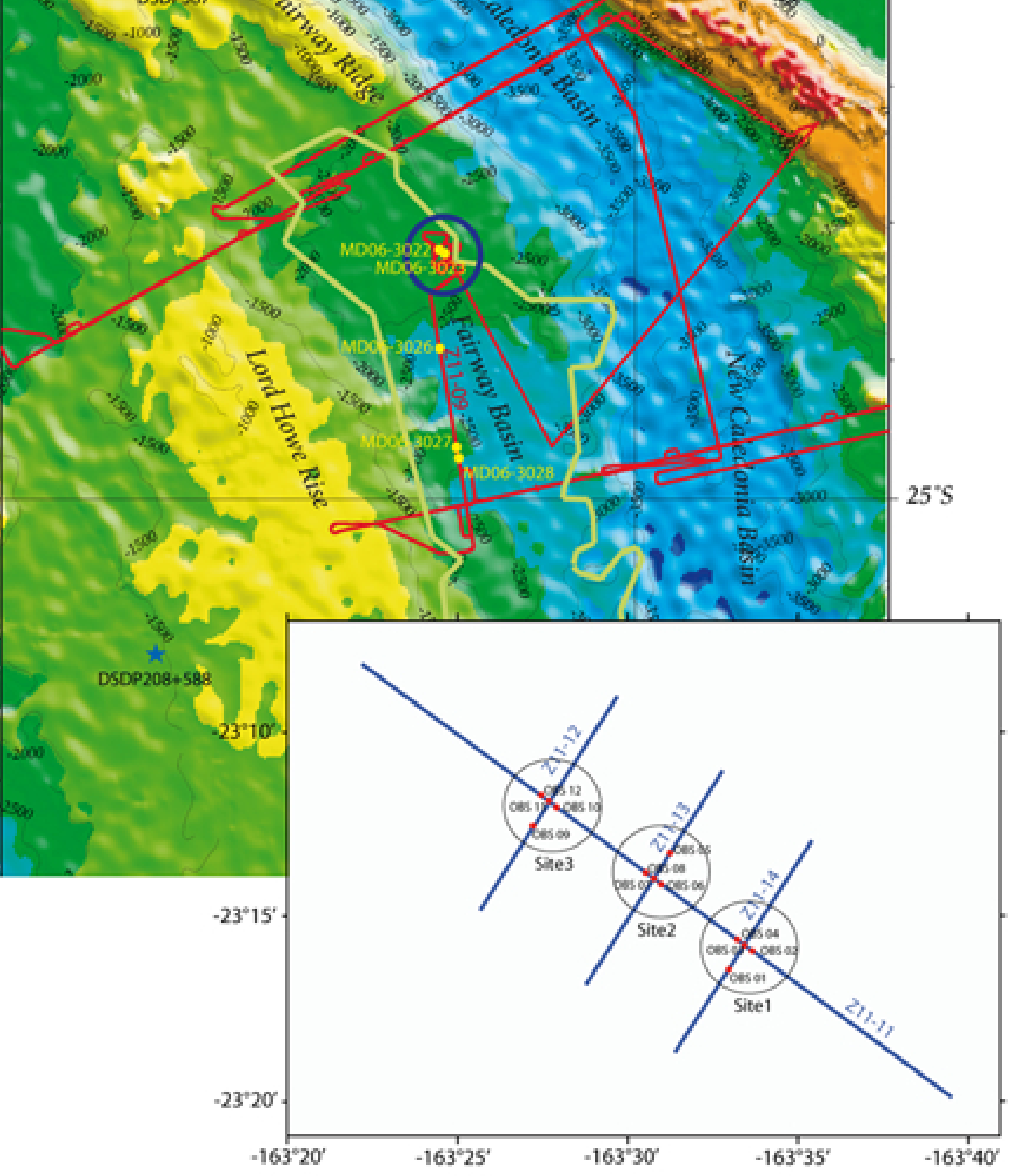
Figure 2

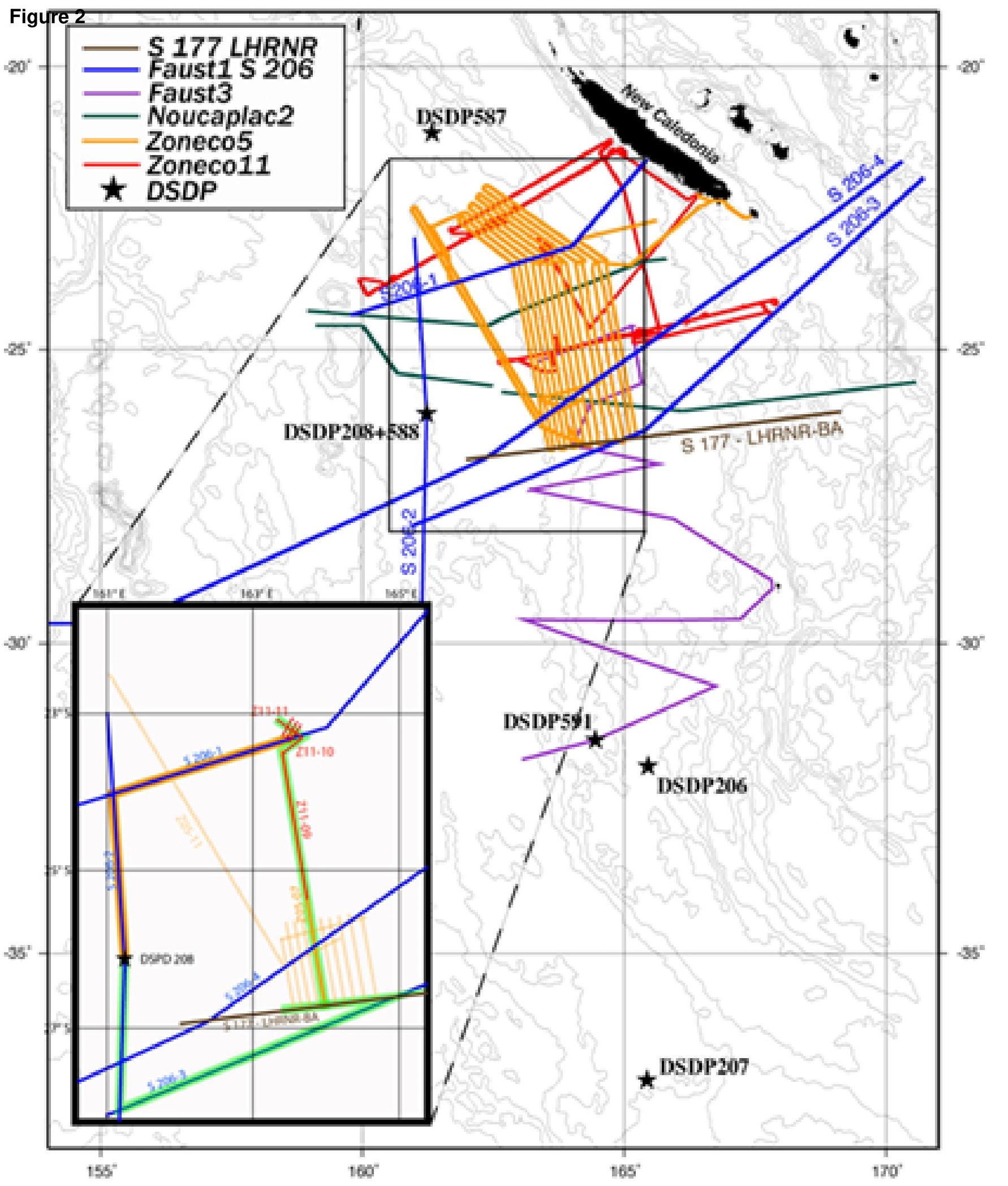




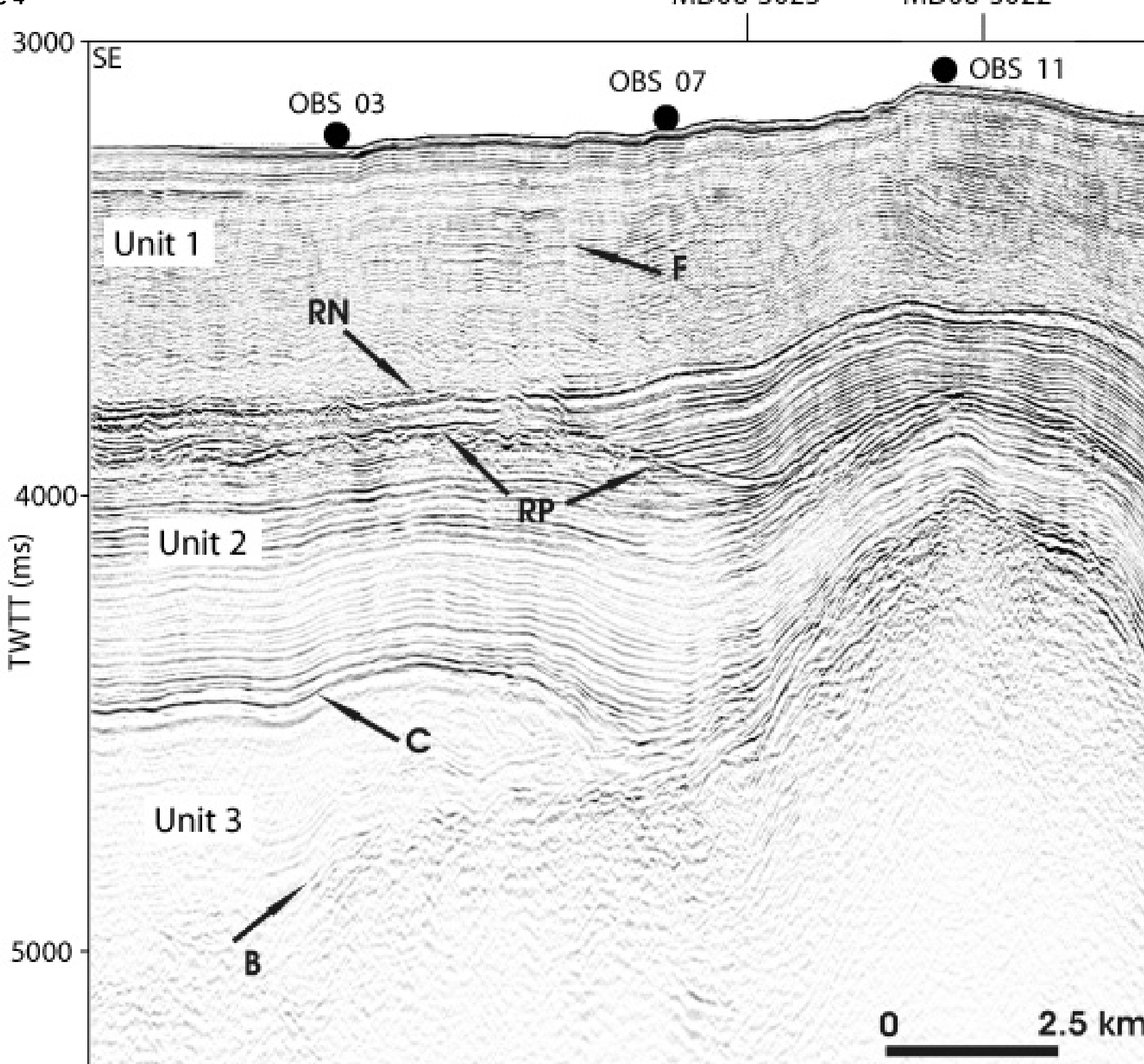




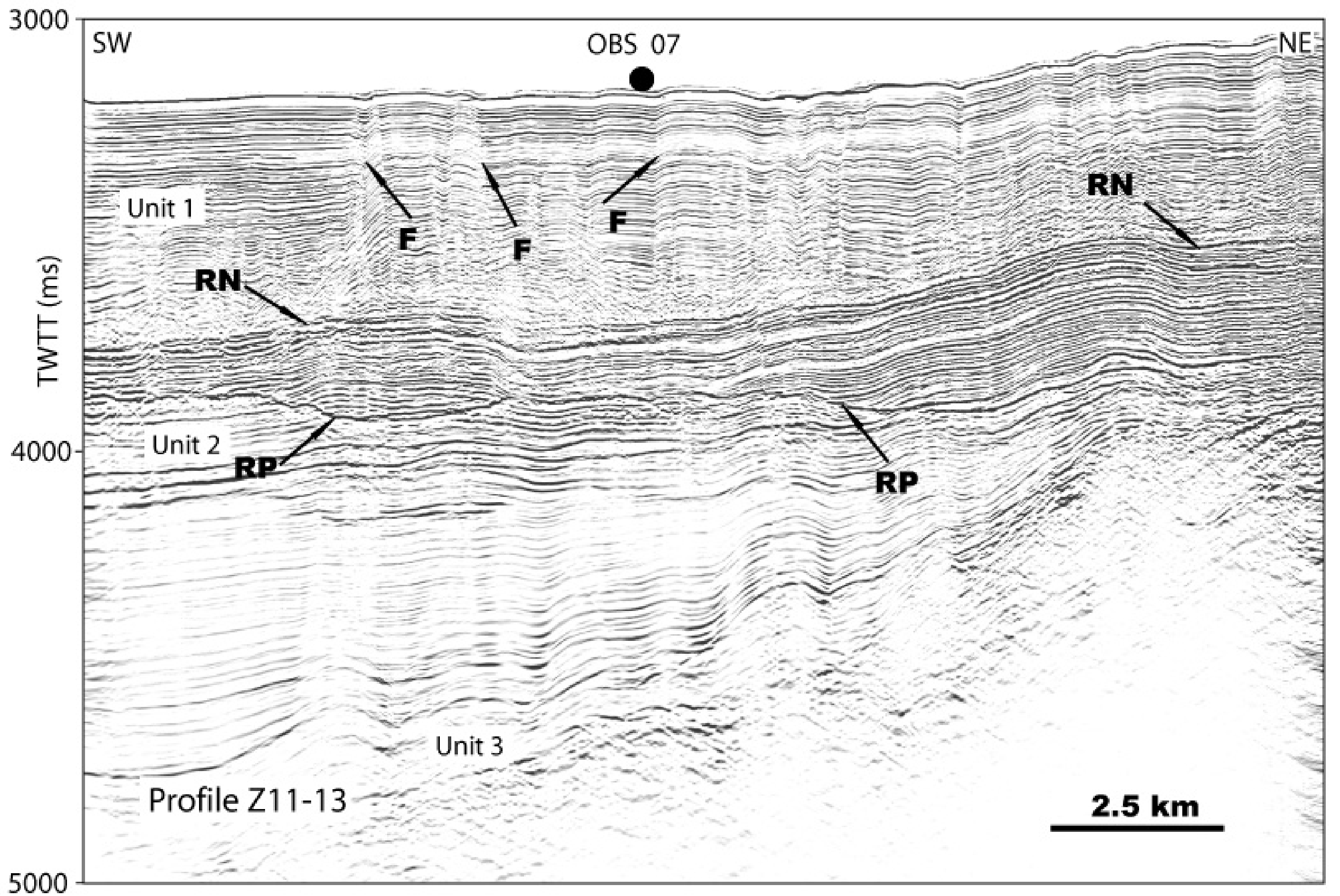




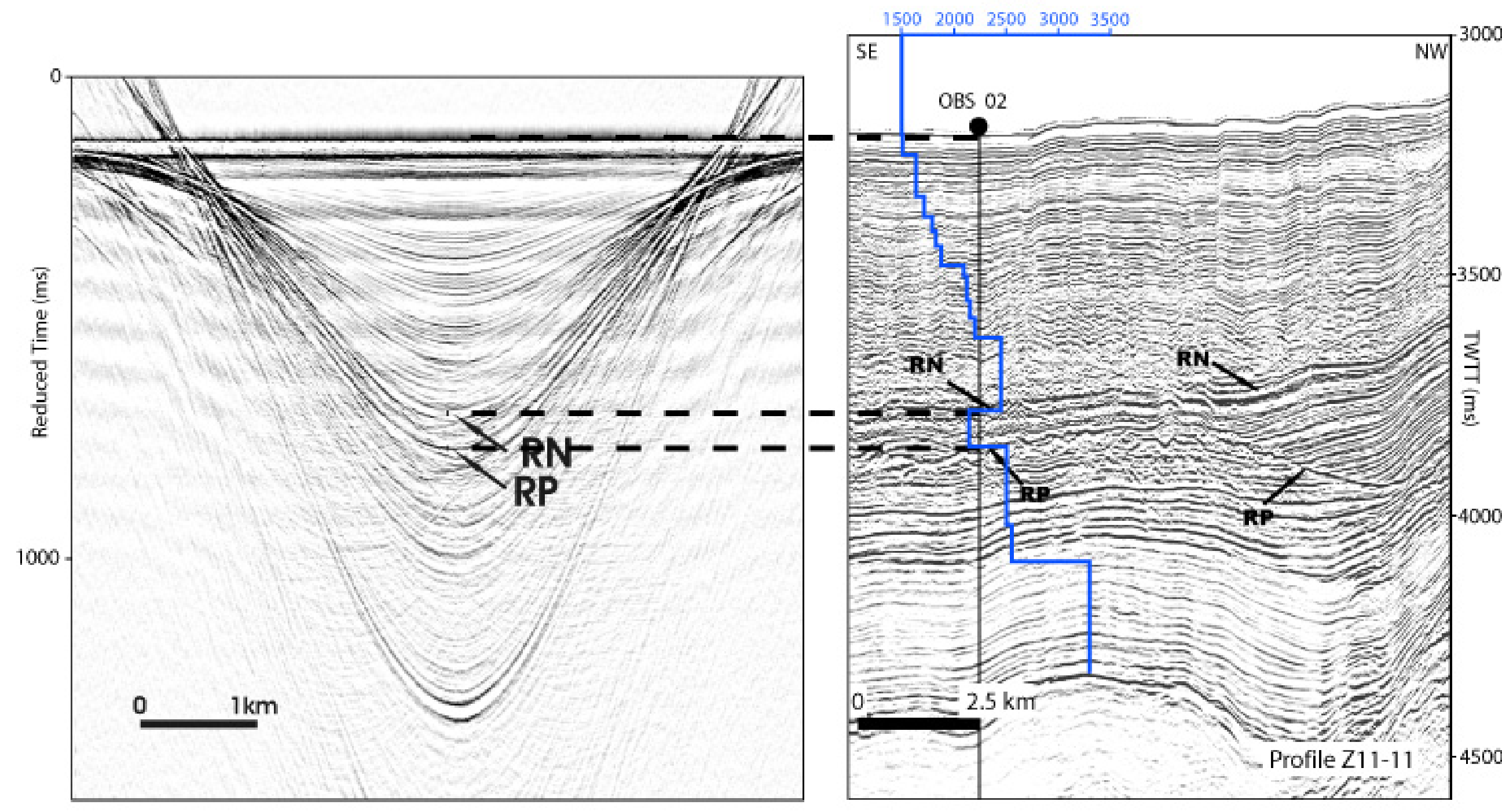




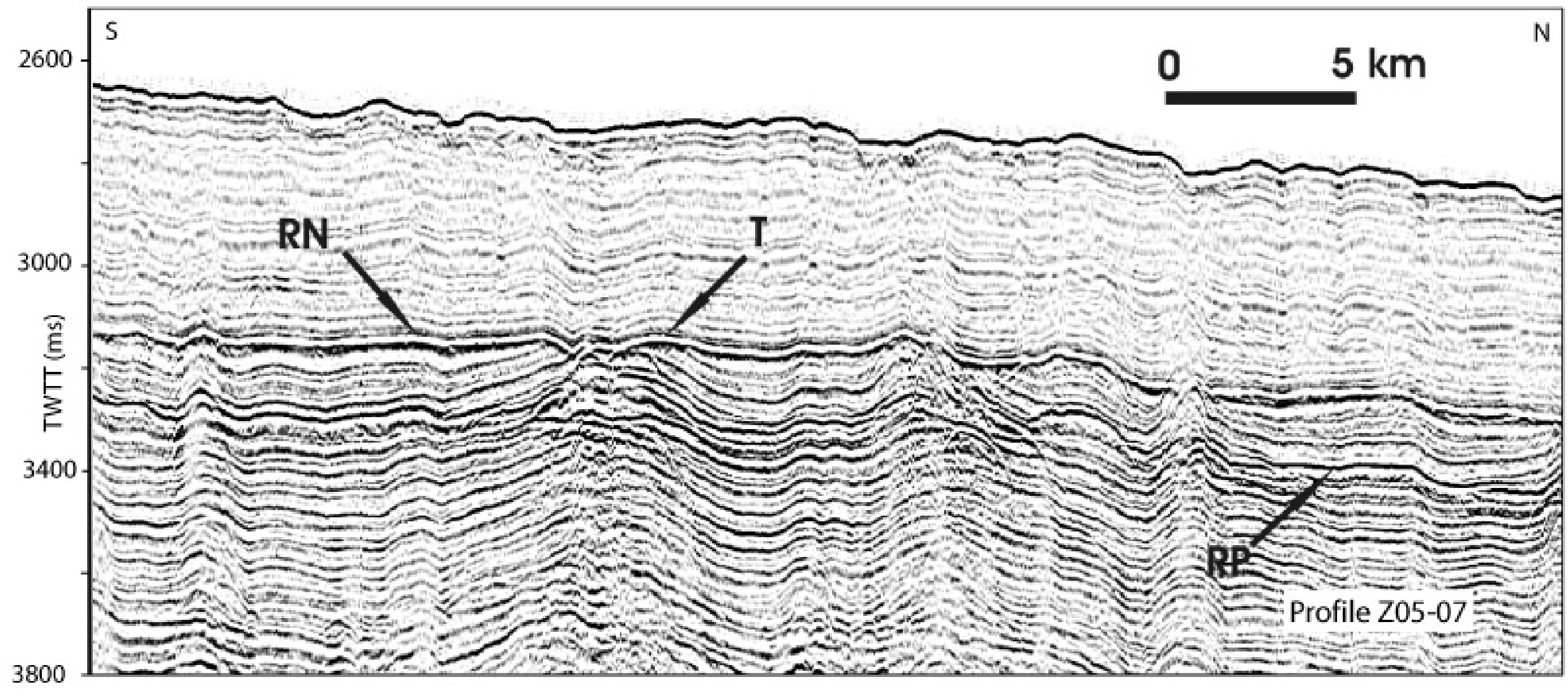


$5 \mathrm{~km}$

点

2500

3000

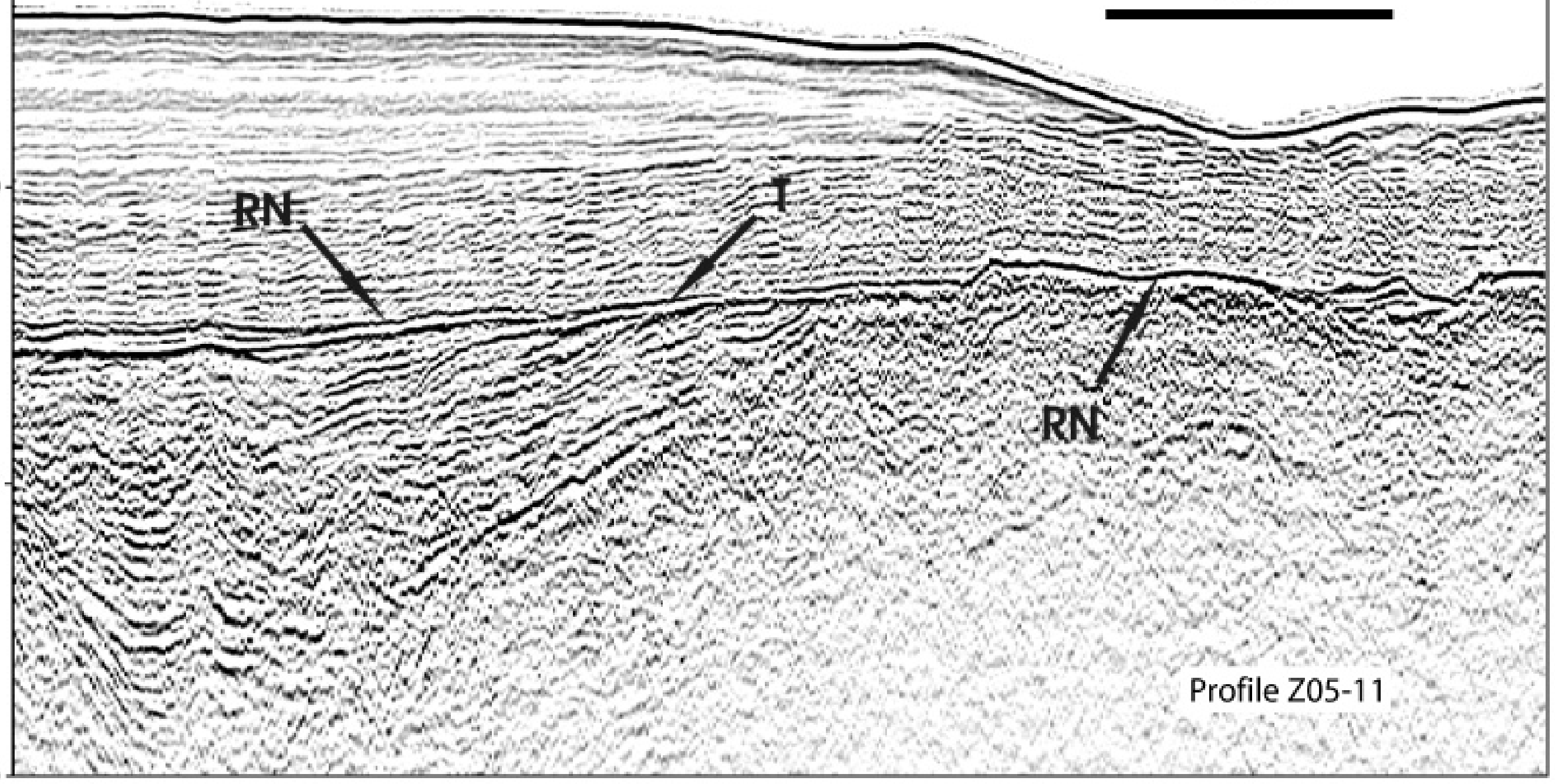



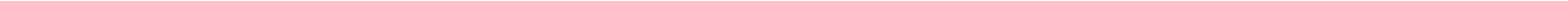

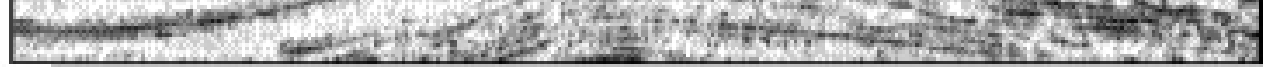

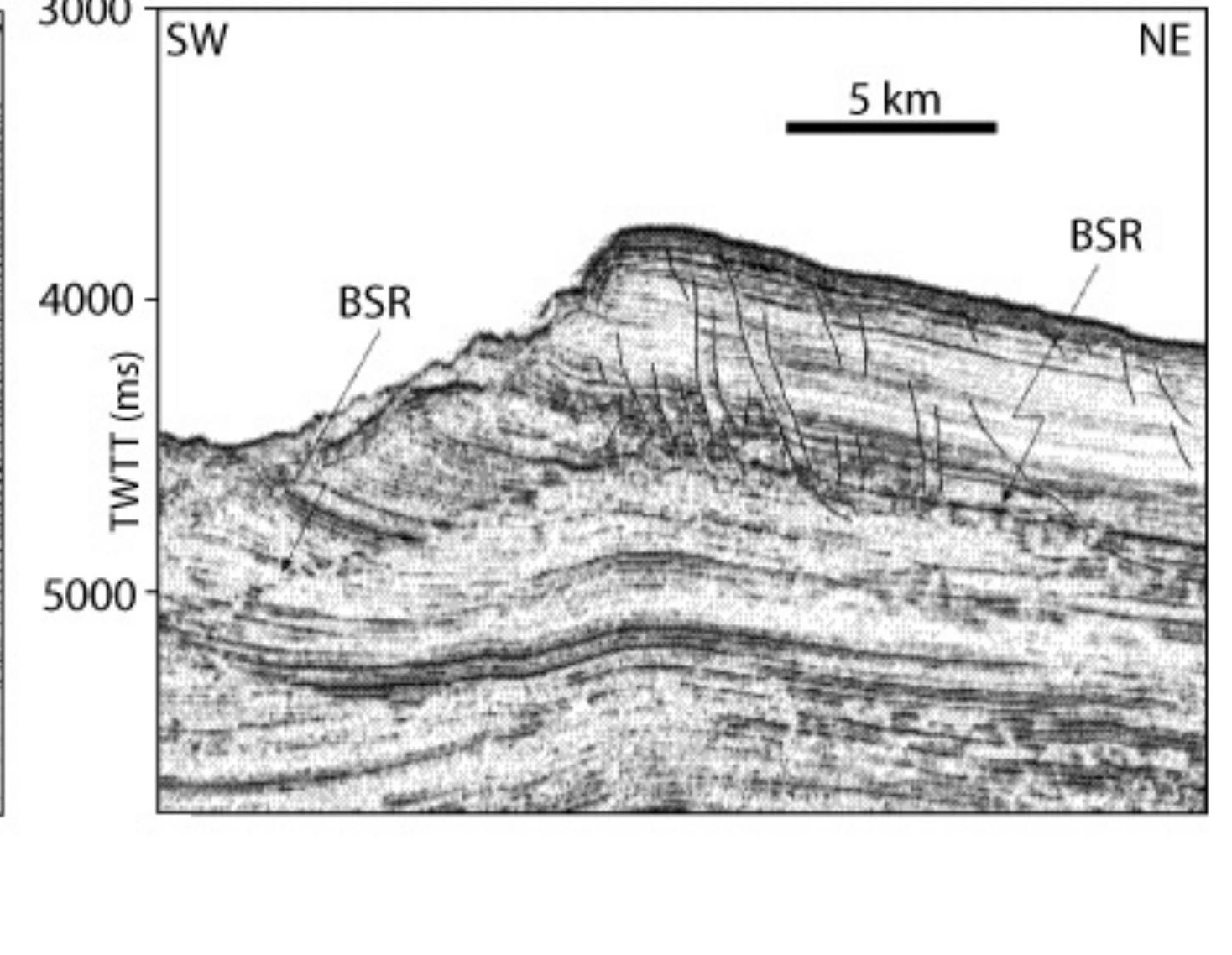

